\title{
Student Perspective on the Institutional \\ Efforts to Develop Internationalisation Within Romanian HEIs
}

\author{
Cristina Ramona Fiț and Delia Gologan
}

\begin{abstract}
Abbreviations
ANPCDEFP The National Agency for Community Programmes for Education and Professional Development

EHEA The European Higher Education Area

ESU European Students Union

IEMU Internationalisation, Equity and Institutional Management for a Quality Higher Education

$\mathrm{HE} \quad$ Higher Education

HEIs Higher Education Institutions

UEFISCDI The Executive Agency for Higher Education, Research, Development and Innovation Funding
\end{abstract}

\section{Introduction}

This study has been developed considering the context of the Bologna Process, as well as the 18 years of experience that Romania has gained while implementing the educational policies that are part of EHEA. Therefore, the aim of this study is to increase the awareness on the strengths and weaknesses of the internationalisation dimension of education in Romania. We intend to do this by better understanding students' perspective on this phenomenon and the range of internationalisation activities initiated by various universities. In the first part, the paper analyses stu-

C. R. Fiț $(\bowtie)$. D. Gologan

National University of Political Studies and Public Administration, Bucharest, Romania

e-mail: cristina.fit@gmail.com

D. Gologan

e-mail: delia.gologan@gmail.com

(C) The Author(s) 2018

A. Curaj et al. (eds.), European Higher Education Area: The Impact of Past and Future Policies, https://doi.org/10.1007/978-3-319-77407-7_9 
dents' perception on internationalisation, presenting the conclusions of a survey taken by 5126 Romanian and foreign students enrolled in the 17 target HEIs, including reasons for or barriers against taking part in a study or placement mobility. Also, the paper offers an analysis of the university strategies on internationalisation, thus showing the perspective of Romanian universities in terms of what dimensions they prioritize, and what institutional measures are taken to integrate internationalisation into the teaching, research, or services of HEIs using as a proxy the objectives found in their strategic documents on the subject. Clarifying these aspects as well as discussing students' recommendations for improving the international dimension of education will help identify, in the final part of this paper, potential solutions to improve the international dimension of the Romanian educational system.

The purpose of this endeavour is to contribute to the improvement of the internationalisation dimension of education in Romania, by understanding more thoroughly the perspective of students, one of the biggest stakeholders in the field of $\mathrm{HE}$ and the potential solutions to improve it.

\section{Methodological Aspects}

This paper focuses on a combined qualitative and quantitative analysis of data collected through a perception survey, followed by a scan of the conclusions emerging from the analysis. Choosing this combined methodological approach served as a driver for reflecting the complexity of the issues tackled by this research paper and the availability of data from multiple sources that needed triangulation in order to answer the RQs. This approach also has some connected limitations that we describe at the end of this paper. For the quantitative part of the analysis, we have investigated the relationship between different variables using nonparametric correlations and the variability among some of the correlated ones using factor analysis.

Data was collected through a survey designed and applied during the "Internationalisation, Equity and Institutional Management for a Quality Higher Education" (IEMU) project.

Section "Internationalisation of HE in Romania-Short Introduction" of this paper presents the qualitative analysis of institutional documents from 19 HEIs that included their objectives regarding the development of the international dimension of their activity.

We are aware of the limitations of this study that have two main sources: the unbalanced sample of respondents and the impossibility of presenting the perspective of other stakeholders regarding the efforts put up by the HEIs. The first of them derives from the fact that an uneven number of students from different universities took part in our survey, thus the sample is not representative for the entire 
student population of the institutions that are part of the study. This could have been solved by factoring-in the sample, but we considered that, at this stage of the analysis, the reached conclusions are relevant even if not representative for the Romanian student or academic population. The second limitation would have been overcome if similar surveys were distributed among teachers and representatives of the HEIs management. This will be done through further initiatives and projects of the authors. However, for this paper, the mitigating strategy that includes analysing the official documents of the institutions that referred to the institutional objectives for internationalisation, reflects both the academics' and the management's perception of the priorities in this domain. (Since these documents were adopted through the voting procedure within the HEIs Senates).

\section{General Context}

\section{Relevance Issues}

The relevance of this paper is given by the fact that it innovatively considers students' opinion on the international dimension of education. The reasons behind this decision lie on arguments of the dimension of this stakeholder, their stake in the process of internationalisation and their characteristics as parts of the HE governance. Students are the largest stakeholder in HE - fulfilling both the role of beneficiaries of the educational process, and that of partners in policy development and implementation, since this was agreed in the context of the Bologna Process, by the Ministers of the EHEA states, in 2001. Moreover, we agree with the ESU arguments that the student input can be not only strong and unbiased but also extremely relevant, as students are, above all, the most interested academic category in providing useful feedback for the improvement of the educational system (ESIB 2001). Their stake is, therefore, bigger in what internationalisation is concerned as it is one policy area dependent on their involvement in the process from the beginning.

Students have already proved their interest in educational policies and perseverance in making a point according to their interest in all the international structures they have been represented since the establishment of The European Students' Union (ESU) in 1982. They have contributed to the development of EHEA and the implementation of the Bologna Process policy lines at national and local level. This is also true for the Romanian students.

As highlighted in the next subsections of the paper, there is a favourable context for discussing manners of improving the dimension of internationalisation in the Romanian educational system. Thus, there is no better moment for surveying the perception and opinion of all stakeholders, especially students, than now. 


\section{Concepts and Definitions}

Given the absence of an agreed-upon definition for internationalisation - the main concept the paper works with - as well as the many perspectives on it, the authors have chosen as a working definition for the paper the one developed in a study and revised Jane's Knight definition (de Wit et al. 2015). This definition describes it as "[t]he intentional process of integrating an international, intercultural or global dimension into the purpose, functions and delivery of postsecondary education, in order to enhance the quality of education and research for all students and staff, and to make a meaningful contribution to society (de Witt et al. 2015). Just as the definition proposed by Jane Knight, the above-mentioned description includes two main related components - "internationalisation at home" and "internationalisation abroad" within the one of internationalisation of Higher Education (2008). And this way of perceiving internationalisation as a process or a set of measures that authorities, at different levels, can implement, stood at the basis of the study presented by this paper and developed the survey questions. It also emphasizes the importance of internationalisation in enhancing the quality of education. Last but not least, it also conveniently builds upon the idea of students as a major stakeholder in the HE system, as well as one of the major beneficiaries of this process and of all public policies and activities related to comprehensive internationalisation.

\section{The Romanian Situation}

\section{Internationalisation of $\mathrm{HE}$ in Romania-Short Introduction}

During the communist period, Romania was actively involved in the internationalisation of HE. "As part of a wider foreign affairs agenda of the pre-1990 communist regime, Romania implemented several strategies to attract foreign students. These strategies included applying lower tuition fees compared to other countries, providing specific services for foreign students, such as Romanian language courses, facilitating access to libraries, and introducing special university regulations, canteens and accommodation arrangements as well as providing a small number of government-funded scholarships" (Pricopie 2004). These policies were successful and, at the beginning of 1980s, Romania was among the top 15 countries in the world providing academic services for foreign students (by then foreign students accounted for $10 \%$ of total enrolments). The number of foreign students declined in the late 1980s and early 1990s, despite new bilateral agreements with Europe, Canada and the US and Romanian membership of the Socrates program (Deca and Fit 2015). 
After the fall of the communist regime, the Romanian ethnicity was addressed as part of a new government policy in the field of education creating a special type of mobility programs. At that time, through the policy, the Government offered students coming from The Republic of Moldova special study grants to attract them towards Romanian universities and determine their enrolment in the Romanian HEIs. This policy is still in place and it has extended the pool of potential beneficiaries to all ethnic Romanians living abroad, though it specifically targets The Republic of Moldova, Albania, Bulgaria, the Former Yugoslav Republic of Macedonia, Serbia, Ukraine and Hungary, as well as other ethnic Romanians living abroad.

Romania has been part of the Bologna Process since 1999 when it signed the Bologna Declaration. From 2004 through 2007, Romania implemented the main Bologna Process reforms, such as switching to a three-cycle system of $\mathrm{HE}$, developing a qualification framework, implementing the ECTS system, issuing a diploma supplement, facilitating recognition of study periods abroad (Egron-Polak 2014).

A strategic influence on Romania's policies on internationalisation and more attention to their implementation was brought along with the opportunity to host the Bologna Ministerial Conference Secretariat in Bucharest, between 2010 and 2012 and organize the eighth Ministerial Conference in Bucharest. During this period, young experts were involved in the Bologna Secretariat, where they contributed to raising awareness on the importance of following the Bologna Process commitments and the specific issues where Romania still had to work on. During that conference, the strategy "Strengthening Mobility for a Better Learning" (EHEA 2012) was adopted as an addendum to the Bucharest Ministerial Communique. As a result, most of these Ministerial Conference recommendations were integrated in the most recent Romanian National Education Law no. 1/2011. Unfortunately, that did not automatically mean instant or full implementation in the Romanian HE system. Lack of secondary legislation, lack of funding or implementation capacity or simply the fact that the provisions changed many times since then are just some of the reasons for this situation. Therefore, Romania has only a few national public policies or strategies targeting the development of and support for internationalisation (UEFISCDI 2013).

Another reason for the prioritization of internationalisation could also be the decrease in the number of students in the Romanian HE system, hence the need to target new potential recruitment pools. However, to attract foreign students, universities needed to become more international. Attracting more students became essential for the survival of universities, which were otherwise forced to gradually resume their economically inefficient study programs.

However, the reality of the Student mobility in Romania is difficult to analyse especially because there is no robust data collecting system for internationalisation, as many experts have noticed, over the years. In many cases, both national and international experts recommended the improvement of the data collecting system 
in order to be able to develop coherent and evidence data-based public policies. That is why, when describing the Romanian situation, one has three alternatives: (1) to initiate an individual effort in collecting raw data and analyse it; (2) to use data collected in European-funded projects and reuse it; or (3) use the only set of data available that dates back to 2011 from the classification initiative of the Ministry.

\section{Student Mobility in Romania-Trends}

Since 2010, Romania has registered a positive trend in international degree-seeking students, their number reaching $5 \%$ of the student population (with an EU average of $7 \%$ ). However, more than half of them are Romanian ethnics living abroad. Thus, Republic of Moldova is the no. 1 country of origin for international students studying in Romania. They benefit from bilateral agreements allowing them to study in Romania in their native language. For the rest of the international students, low tuition fees, low living costs and a large number of available study placesespecially in medical programmes, are very attractive, and less attractive is the level of development of the international dimension of the Romanian HE system.

Compared to these students, there are almost three times more Romanian students seeking degrees outside of the country - the top three destinations for them are the UK (5900 students), Italy (5700 students) and France (4200). ${ }^{1}$

The same proportion is reflected among students involved in credit mobility programs: there are three times more students going abroad to study or work (6885 outgoing students in 2014-2015), than those coming to Romania (3418 incoming students in 2014-2015), but the overall number of students involved in such mobility programs is still low (ANPCDEFP and CPEDU 2015).

In terms of a strategic document in the field, Romania has no national strategy on internationalisation of HE endorsed by the Ministry of Education, only a proposal developed during the IEMU project, in 2015. In 2016, the Ministry created a working group appointed to finalize a national strategy on internationalisation, but unfortunately, in 2017, it did not record any progress (the Government changed and meetings of the WG were resumed).

To conclude, this article takes all these observations-the status of the internationalisation dimension, the demographic challenges, the opportunity to develop the internationalisation etc. - and suggests a way forward. This refers to using the perspective of students on this area in order to develop it. The following two sections of the paper aim to do exactly this.

\footnotetext{
${ }^{1}$ Dataset available online, here: http://data.uis.unesco.org/Index.aspx?queryid=172 (UNESCO Institute for Statistics - Outbound internationally mobile students by host region).
} 


\section{Results and Discussions}

\section{The Perspective of Romanian Universities}

An analysis (during the IEMU project ${ }^{2}$ ) of the strategic plans of $19 \mathrm{HE}$ institutions (UEFISCDI 2015) was conducted and revealed the goals and objectives for internationalisation of Romanian universities. Despite the natural differences between universities, as well as their mission and context, that determined normal differences in their strategies, the authors of the UEFISCDI study also observed some similarities (2015). For example, most of the institutional strategies covered the areas of internationalisation at home, mobility, research, marketing, partnerships, services for international students and areas regarding the quality of education and internal organization matters. All universities had goals related to internationalisation at home, namely developing programs taught in foreign languages, developing foreign language skills for the teaching staff, attracting international speakers and staff. The authors considered this as a proxy for the interest the university has for these aspects of the international dimension of education. Unfortunately, the study also revealed a limited understanding of the concepts linked to internationalisation, as there were no signs of intending to internationalize the curricula of the offered programs - for example. Moreover, there were no signs of their intention to develop internationally relevant competencies as part of the intended learning outcomes. Increasing mobility was also a goal of all institutional strategic plans, focusing on both incoming and outgoing mobility, and only in few cases, the importance of the qualitative aspects of mobility was highlighted. Research is still one of the main areas that universities are very interested in, this being the area that enables teachers to improve their career and that supports other initiatives in internationalisation. The goals for this area of interest were related to increasing research partnerships and attracting new funding opportunities and researchers. More attention was paid to increasing the number of partnerships than to the importance of choosing them strategically. Marketing and promotion were, as well, a core goal focusing on increasing the university's international visibility and developing a dedicated marketing strategy to become more visible in the international area, thus attract more students. In terms of partnerships, the focus was on increasing the number of partnerships and involvement in international networks, without taking into consideration the importance of choosing these in a strategic way. Half of the analysed universities had goals related to improving student services, but none of the institutions mentioned improving staff services. It is a positive thing that most of the institutions developed institution goals based on results of surveyed international students.

\footnotetext{
${ }^{2}$ IEMU - Internationalisation, Equity and University Management for a Quality Higher Education — project developed during 2014-2016 by UEFISCDI.
} 
Other goals mentioned in their institutional strategies were related to the third mission of the institution, involvement in the local community and start partnerships with local businesses (companies, local branches etc.), becoming an important regional stakeholder, building an alumni network, developing online and/or blended programs, including the use of MOOCs.

\section{The Student Perception}

\section{Demographic Profile of Respondents}

The results of the survey (developed during the IEMU project) taken by 5126 Romanian and foreign students enrolled in the 17 target HEIs are presented below. Out of the total number of respondents, 5.7\% are foreign students and $94.3 \%$ are Romanian students, while $61.7 \%$ are male and $38.3 \%$ female. Most of the respondents were at the time enrolled in a BA programme- $83 \%$, while $21 \%$ in a MA programme. Out of the total number of respondents, $2.1 \%$ were Ph.D. students and $2 \%$ identified themselves with none of the categories, which means they were probably post-doc students or individuals following post-university studies etc.

As far as their distribution over the study fields, respondents cover all major study fields and reflect more or less the student population in Romania: $41.3 \%$ study Social Sciences and Sport, 17.7\% Engineering Sciences, 17.1\% Mathematics and Natural Sciences, 10.6\% Humanities and Arts, 7.8\% Biological Sciences. 5.4\% of the respondents gave invalid responses, thus falling in the Not defined category.

\section{Perception of the Level of Internationalisation of the Romanian HEIs}

Most of the students consider that their HEI is internationalized, but not in a very deep and meaningful way or they consider that their university is channelling only a small percentage of their resources towards internationalisation. However, students from various fields of study have considerably different perceptions on the internationalisation activities performed by the university. This could be explained in two ways. First of all, certain universities or faculties might have at hand more resources to spend on these issues, thus their efforts to internationalize their institution would be more visible. For example, students in the Economic field of study are privileged in this way, as their faculties attract many students, most of them paying high tuition fees, thus their institutions have a large budget to work with.

On the other hand, there are certain study fields that traditionally attract many foreign students in Romania. For example, $50 \%$ of the students enrolled in Medical programmes are foreign students choosing to study in Romania due to the low tuition fees, compared with their countries, or due to the severe quotas on these programmes in their home states. Obviously, the HEIs with Medical programmes 
are more advanced in implementing all the mechanisms and instruments of the international dimension, thus the respondents coming from these universities are prone to considering their institution more international.

These aspects could be further explored in order to answer the questions about the source of the observed dissimilarity among study-fields and/or institutions in what perceived internationalisations is concerned. It could be due to the fact that different institutions have differentiated access to international activities because students are involved differently, or because these students have distinct expectations from their universities regarding its international activity, therefore they are not satisfied with the same initiatives undergone by the institution.

However, these observations might be hindered by the fact that the study did not include a stage of pondering the results from different clusters of respondents in order to unify the difference in volume of the clusters - as explained above.

Our first hypothesis was that the perception of internationalisation differs with the field of study and there were signs pointing into the direction of verifying this premise. However, no statistically significant correlation was identified between the study field of the respondents and their perception of the level of internationalisation of the institution they are enrolled in (Fig. 1).

As explained in the previous sections of this paper, internationalisation means different things to various people, therefore it was of interest for us to explore the possibility of understanding what are the proxies considered by the students when thinking about an internationalised university. We used the responses to answer the following question: "What do students take into consideration when they say their university is very international?"- a question that could also offer insights over "What efforts undertaken by universities to develop more internationalized HEIs do students perceive as being implemented and working?".

From the respondents that consider their university "very internationalized", $81 \%$ responded that their HEI has the website available in different languages, $86 \%$ that there is a variety of international subjects to choose from, $82.8 \%$ said that some programs or courses are delivered in English, or other foreign languages. Moreover, $74 \%$ consider that the university looks international when you walk around, $85 \%$ consider that there are international activities and events, $73 \%$ find that the library has a wide range of international texts and $57 \%$ agreed that signs are written in different languages. All these proved to be positively correlated with having international students (Table 1).

In terms of information, $89.5 \%$ of the respondents consider that their HEI gives opportunities to study, work, or volunteer abroad, $82.6 \%$ find that there is good information about study, work, or volunteering abroad and $70.4 \%$ find the International Relations Department as helpful (Table 2).

However, when testing the relationship between grading one's university as very internationalised and all the elements of internationalisation, a correlation proved to exist with the following affirmations:

- My programme prepares me to work in an international environment (prepare).

- Teachers encourage study/work/volunteer abroad (encourage). 


\section{The perception of students over the international dimension of their university according to their field of study}

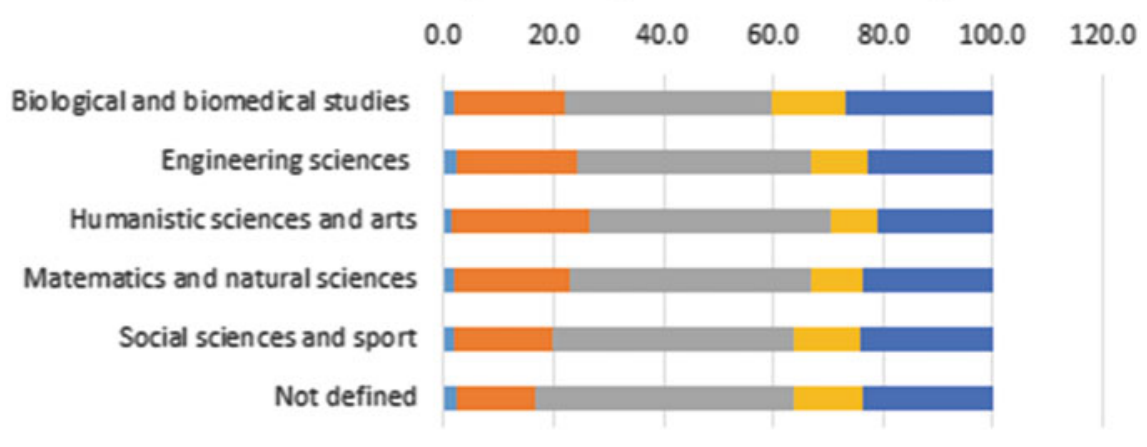

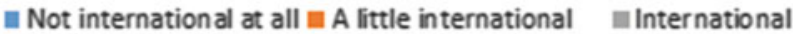 $\approx$ Very international $\quad$ NA}

Fig. 1 Perception of students on the international dimension of their university according to fields of study

Table 1 Correlation between (1) being perceived as able to welcome international students and (2) being perceived as offering them opportunities to mingle, with all the tested elements of internationalisation (website in a foreign language, English study programmes, etc.) all gathered in one overstanding indicator-I1

\begin{tabular}{l|l|l|l}
\hline & & Welcome & Mingle \\
\hline \multirow{2}{*}{ I1 } & Correlation coefficient & $0.306^{* *}$ & $0.330^{* *}$ \\
\cline { 2 - 4 } & Sig. (2-tailed) & 0.000 & 0.000 \\
\cline { 2 - 4 } & $\mathrm{N}$ & 3913 & 3913 \\
\hline
\end{tabular}

**Correlation is significant at the 0.01 level (2-tailed)

Table 2 The link between the perception over the activity of the international department and the perception over the availability of data about the mobility opportunities, as well as the link between the perception over the number of mobility opportunities (study, working or volunteering) and the perception over the availability of data about them

\begin{tabular}{l|l|l|l}
\hline & & Opps_A & Depart \\
\hline \multirow{3}{*}{ Info } & Correlation coefficient & $0.429^{* *}$ & $0.331^{* *}$ \\
\cline { 2 - 4 } & Sig. (2-tailed) & 0.000 & 0.000 \\
\cline { 2 - 4 } & $\mathrm{N}$ & 3913 & 3913 \\
\hline
\end{tabular}

*Info $=$ There is good information about study work volunteering abroad

*Depart $=$ There is a helpful International Relations Department

*Opps_A $=$ There are opportunities to study work volunteer abroad

$* *$ Correlation is significant at the 0.01 level (2-tailed) 
- My programme helps me develop an international outlook (outlook).

- International opportunities are included in the programme (Opps).

- There is the opportunity to study another language (languages).

- Academics and support staff are aware of European global issues

- There are teachers from other countries in my programme (Acad_foreign).

A complementary correlation was tested positive with the elements that influenced the respondents to rate their university as very poorly internationalised - the university is perceived as lacking:

- A choice of international study subjects (IntlSubj).

- International activities and events (intlAE).

- Signs in different languages (sings).

- Capacity of welcoming international students (welcome).

- Activities and events that help home students and those from other countries to mingle (mingle).

- Openness of Support staff (staff_open).

- Capacity of support staff to speak other languages besides Romanian (staff_global).

- Capacity of academic staff to speak other languages (languages_A).

The third hypothesis tested was whether there is a positive correlation between the participation in a mobility program facilitated by the university and the perception that it is "internationalised", thus that students who have been in an international mobility tend to say their university is international.

As seen in Table 3, we have failed to reject this hypothesis, since we have a correlation level between the two variables of $r=0.475, p<0.001$, that is participants in a mobility program tend to perceive their home institution as more internationalised. This could be explained in two ways: either, these students consider their institution internationalised based on the fact that it offered them the opportunity to study, work or volunteer abroad and this is enough for them; or they are more perceptive to the elements of internationalisation, thus more easily observing them among the efforts of their university. This was surprising since our expectation was that students who have participated in an international mobility, and have already met another international institution, thus being able to compare it with their home university, will be more critical with the latter.

When testing for the relationship between the perceived internationalisation level of HEIs and other characteristics of academic and support staff, we found only one statistically significant relationship. In universities where support staff is perceived as being open to international students, it is more likely for respondents to perceive the institution welcoming to international students. 
Table 3 Relationship between level of internationalisation and participation in a mobility

\begin{tabular}{|c|c|c|c|c|}
\hline \multicolumn{5}{|l|}{ Correlations } \\
\hline & & & Internationalization & Mobility \\
\hline \multirow[t]{6}{*}{$\begin{array}{l}\text { Kendall's } \\
\text { tau_b }\end{array}$} & \multirow[t]{3}{*}{ Internationalization } & $\begin{array}{l}\text { Correlation } \\
\text { coefficient }\end{array}$ & 1.000 & $0.417 * *$ \\
\hline & & \begin{tabular}{|l|} 
Sig (2-tailed) \\
\end{tabular} & . & 0.000 \\
\hline & & $\mathrm{N}$ & 5126 & 5126 \\
\hline & \multirow[t]{3}{*}{ Mobility } & $\begin{array}{l}\text { Correlation } \\
\text { coefficient }\end{array}$ & $0.417 * *$ & 1.000 \\
\hline & & Sig (2-tailed) & 0.000 & . \\
\hline & & $\mathrm{N}$ & 5126 & 5126 \\
\hline \multirow[t]{6}{*}{$\begin{array}{l}\text { Spearman's } \\
\text { rho }\end{array}$} & \multirow[t]{3}{*}{ Internationalization } & $\begin{array}{l}\text { Correlation } \\
\text { coefficient }\end{array}$ & 1000 & $0.475 * *$ \\
\hline & & Sig (2-tailed) & . & 0.000 \\
\hline & & $\mathrm{N}$ & 5126 & 5126 \\
\hline & \multirow[t]{3}{*}{ Mobility } & $\begin{array}{l}\text { Correlation } \\
\text { coefficient }\end{array}$ & $0.475 * *$ & 1.000 \\
\hline & & Sig (2-tailed) & 0.000 & . \\
\hline & & $\mathrm{N}$ & 5126 & 5126 \\
\hline
\end{tabular}

**Correlation is significant at the 0.01 level (2-tailed)

\section{Mobility Programs: Reasons and Barriers}

One of the most well-known aspects of internationalisation is mobility of students. In Romania, mobility programs are sometimes mistakenly associated as the only part of the internationalisation dimension of the university, thus the only one that is in the focus of data collection efforts - as section "General Context" has shown. Mobility programs are more or less the only activity in which students are directly involved, not only as beneficiaries but also in the process of decision-making or implementation of public policy. That is why a great part of our questionnaire addressed the issue of student mobility programs in trying to find out the students' perspective on their implementation. The aim was to identify the positive aspects/ reasons for and barriers in the way of attracting more students in participating in mobility programs. The other aim was to identify potential solutions from the students' perspective to improve the mobility programs and the international activity of the university.

Out of all responses, 19\% have participated in a mobility program (study mobility, placement/internship programs), 37\% did not take part in any mobility, but they would like to try one in the future, and $19 \%$ of respondents did not participate in a mobility. Unfortunately, 23\% did not answer this question, thus their status is unknown.

Out of the total mobile students, $61 \%$ had a study or research mobility experience, $36 \%$ underwent a placement mobility (being involved in a job/internship) and 
Table 4 Distribution of respondents according to the perceived level of internationalisation of their institution and their previous experience in a mobility program

\begin{tabular}{l|c|c|c|l}
\hline & Yes (\%) & No $(\%)$ & NO, but I would like to go (\%) & NA (\%) \\
\hline Very international & 3.14 & $\mathbf{2 . 3 0}$ & 5.63 & 0.11 \\
\hline International & $\mathbf{1 1}$ & 11.21 & 20.85 & 0.17 \\
\hline A little international & $\mathbf{4 . 6 0}$ & 5.22 & 9.91 & 0.01 \\
\hline Not international at all & 0.56 & $\mathbf{0 . 4 2}$ & 1.09 & 0 \\
\hline
\end{tabular}

Yes - they have already been part of one; No - they did not get this chance; No, but would like to go

Table 5 Contingency table of conditional proportions for the two variables: owning a website in a foreign language and having an international student community

\begin{tabular}{l|l|l|l}
\hline & \multicolumn{3}{|l}{ International student community } \\
\hline $\begin{array}{l}\text { Website in foreign } \\
\text { language }\end{array}$ & Yes & No & $\begin{array}{l}\text { Not } \\
\text { know }\end{array}$ \\
\hline Yes & 0.789617 & 0.65625 & 0.714286 \\
\hline No & 0.076503 & 0.16875 & 0.061224 \\
\hline Not know & 0.13388 & 0.175 & 0.22449 \\
\hline
\end{tabular}

$12.9 \%$ had a mobility as a volunteer. Only $2.92 \%$ out of all mobile students had the chance to take up all three types of mobility opportunities.

According to this contingency test, one can conclude that providing a website translated in a foreign language can have a direct impact on the potential of growing the international student community.

Our hypothesis as for the reasons that determined students to follow a mobility program was confirmed, as respondents mentioned, among the most important reasons for choosing a study mobility, the following: personal development opportunities (88\% of respondents), new career opportunities $(83 \%)$, and taking up the financial opportunity (67\%). In addition to these reasons, students also mentioned that an element they considered attractive and a good reason for them to go on a study mobility was the opportunity to follow a course or a program unavailable in their home-institution (38\%). The support of their family and friends was one of the reasons encouraging $18 \%$ of the respondents to take up this opportunity.

The lack of financial resources is one of the well-known issues linked to lack of access to education or the reason for early drop-out, and one of the most frequently mentioned barriers (47\%) that stands in the way of more students embarking on a mobility program (study/research/working mobility). It is commonly known that the Erasmus + grant is not enough to cover the real costs of the mobility, thus universities request students to manage the difference (e.g. by requesting financial support from their families or taking up loans with this purpose). However, many of them cannot receive this kind of help. In this position, one can observe especially those students coming from categories that are already under-represented within the educational system and face high risks of social exclusion. They are usually students with several combined risk factors, namely they come from rural environments, from poor families, with parents who do not have high levels of education, thus have small chances to earn enough in order to support them financially. 
Moreover, they lack the appropriate previous education (e.g. high levels competencies in languages or knowledge about the cultural aspects of other countries) or the life expectations to motivate them to engage in this effort and to believe they deserve such an experience and can make it possible. These elements would prevent them not only from applying for a mobility grant but also from having a pleasant and successful experience abroad, should they be given this chance.

However, there are other reasons that make students reluctant to apply for a mobility, such as incomplete information about the process (18\%), few opportunities available - that are distributed based on merits, thus only very few privileged students benefit from them- $(18 \%)$. In addition, the lack of moral support from families or friends (14\%) - for e.g. the fact that none of their friends/colleagues participated in such a mobility (11\%), or the anticipated difficulties upon return is a turn-down $(6 \%)$ too. As a conclusion to the information above, we could say that there is not enough counselling (from the HEI level) and information sharing regarding the process of applying and the benefits of taking a mobility.

\section{Students' Recommendations for Developing Internationalisation}

Students were asked to suggest a few ways in which they consider their university could improve its international dimension. $49 \%$ of the respondents mentioned the importance of developing more international cooperation opportunities, inviting more foreign academics to teach within the university (39\%), offering more courses in English even for home-students (31\%), and attracting more international students $(32 \%)$ in order to ensure a more diverse learning environment $(32 \%)$. Courses taught in foreign languages would contribute to the development of appropriate language competencies among students, thus helping them when applying for a mobility abroad.

Other suggestions were to raise the level of decision-making transparency, improve the promotion of mobility opportunities, and raise the capacity of teachers to teach in foreign languages, develop MOOCs and online courses, adapt the curriculum so that it follows international trends, organize alumni events, and invite professionals to share their previous mobility experience. They considered that organizing events where students can share their international exchange experiences would be of great help, as well as hiring new/more staff for coordinating the process and organizing a "buddy system" (tutoring) or finding manners to expose home students to multicultural environments (ANPCDEFP 2013). All these would also help increase the participation of students in mobility programs.

Other similar studies in the field revealed in 2015 other student recommendations that included (ANPCDEFP and CPEDU 2015): 
- Increasing the transparency of study/exchange programmes by offering relevant information in a way that best suits the needs and expectations of the interested parties;

- Making the funding available upon departure;

- Increasing the value of the grant;

- Offering more support to beneficiaries in covering the paperwork, finding accommodation, and solving other logistic issues; Reducing paperwork and bureaucracy specific to the programme.

Looking at the suggestions offered by students, one could say they have a good understanding of the HE policy-making processes, some of the recommendations are consistent with the agreed directions of the Bologna Process in the Ministerial Communiques, and their recommendations are aligned with the authors' opinion. However, they are obviously not familiar with all the elements of internationalisation at home, thus not many of them are found in the list of students' recommendations.

\section{Conclusions}

Having analysed all these data, we conclude that despite the already registered efforts of the universities regarding the development of their international dimension, they have a long way to go to fully develop it.

\section{Strengths}

Even though students from different fields of study have very polarized perceptions of the internationalisation of their university, most of the respondents consider that their university is internationalised. When characterising their university as such, students appreciated different efforts undertaken by their institutions. Some considered that the most important thing is to have a website available in a foreign language, some courses or programmes delivered in English or the possibility to choose from a course offer that included international subjects. Others appreciate more an international-looking campus, the availability of international texts or materials in the library, the offer of events or activities with international participation etc. However, the majority of the survey respondents still appreciate the most the efforts made by their HEI regarding the opportunities to study, work or volunteer abroad, and mobile students tend to appreciate that their university is more internationalised. 


\section{Weaknesses of the Internationalisation Dimension}

However, the general perception is that the efforts towards internationalisation are only occasional and lack in depth and a strategic approach, while many of them still only refer to organizing mobility programs. Unfortunately, students do not perceive many of these efforts, thus proving that one of the main weaknesses of the internationalisation initiatives is communication with the students. In the absence of other efforts, these mobility programs will only be able to send Romanian students abroad, to study, work or volunteer, and not to attract international students or academia. Thus, the number of mobility beneficiaries is still small, as students are not motivated to embark on such experience, nor helped to overcome the perceived barriers.

The study reveals the student perception on internationalisation is limited and that only some of its elements have an impact or are actually visible to students. This makes us believe that it would be useful to teach students what is comprehensive internationalisation, through trainings or lectures, in order for them to fully understand the internationalisation of $\mathrm{HE}$ and see all the possibilities they have at hand to further contribute to the development of this. This can enable them to provide comprehensive feedback not just for mobility programs but for all internationalisation processes undergone by their university.

\section{Motivations and Barriers Encountered by Students When Considering Being Part of a Mobility Program}

Furthermore, this study provides relevant data and observations of the obstacles and barriers to mobility, which can be connected with institutional and national policies on internationalisation as a good starting point to improve these policies. Out of these results, we can understand the type of policies or regulations universities could develop in order to encourage students to go on a study or placement mobility, leading to prepare active citizens for the global market and meet the EHEA target of $20 \%$ of international students abroad by 2020 . Even though this target is set at a European level, Romania still has to improve its percentage of outgoing and incoming student mobility. In addition, we recommend that universities focus more on implementing and developing new policies such as creating special scholarships or other financial incentives for those who want to go abroad. It is well known that EU grants are not enough for students, and not being able to cover the remaining costs is the main reason why most students do not want to take part in a mobility. As recommended in the 2012 "Mobility for a better learning" strategy, there is a need for developing awareness campaigns for students, academics and parents in order to better understand the goal and importance of a short-term mobility abroad and the impact these could have on the development of a student in becoming an EU active citizen with a complex skill set. Furthermore, 
counselling centres for students who want to go on a mobility would also be helpful in order for students to have the courage to take a mobility opportunity, be prepared for such an experience and understand the impact this activity could have on his/her personal and professional development.

The choice of going to study abroad for a period is justified by the possibility to personally and professionally develop during that period, thus becoming more employable. The most common reasons for students not engaging in outward mobility are financial difficulties experienced abroad or inadequate support from the home university. The latter translates in a small number of opportunities, lack of updated information and of cooperation for recognition of the study period abroad for the student returning home. Students provided their feedback on the exchange/ mobility program in terms of positive aspects and issues that still require fine-tuning in the recommendations section.

\section{Institutional Perspective on the International Dimension}

From the analysis of the institutional documents regarding internationalisation, one can conclude that endeavours towards it represent small efforts directed towards many elements, with no prioritised directions that could add value to the university. Unfortunately, most of the efforts are still built around the mobility programs and sometimes for research.

\section{Recommendations}

It is important to emphasise the need for more efforts to be directed towards making these processes more transparent, better promoted and communicated among the potential beneficiaries. Also, there is a need for a better-facilitated access to the information regarding the mobility process through specialized centres. The available support needs to cover financial needs, emotional needs (empowerment, motivation) and academic needs (academic requirements to study in another country and ease of recognition of the mobility program upon return). As well, there is a need for understanding the students' perception of the benefits and risks of internationalisation and align more the mobility aspect of internationalisation with the internationalisation of the curriculum, teaching and learning.

As a recommendation, we suggest developing internationalisation at home in all its aspects (internationalised curricula, more international students and international staff etc.)

More funding is needed both for developing more international cooperation opportunities, offering more English-taught or internationalised courses or improving the marketing of mobility opportunities, but also for investing in developing the institutional and human capacity of HEIs for internationalisation. 
Better funding would allow the use of technology for improving the bureaucratic processes related to internationalisation as well as enabling more support to mobile students (moral and logistical), both before, during and after the mobility period. All these and a consistent data collection system for making informed decisions that might help improve the international dimension of the Romanian educational system.

As a recommendation on the Bologna Process, in order for the $20 \%$ mobility goal to be achieved, there is a need for more financial investment from all participating countries, as well as empowerment policies and programmes for students in order for them to understand the importance of internationalisation in all its aspects (internationalisation at home, curricula, teaching or mobility etc.). In the context of current heavy migration, the EHEA should take serious action and develop possible national/European policies and include workshops, courses and programmes in the members' institutions regarding diversity with all its aspects. Withal, better marketing for placement mobility together with special benefits for companies and institutions that could financially support students during their mobility period should take students' perception of the importance of internationalisation and the fact that internationalisation (e.g. mobility) can happen to another level of trust and awareness. As well, more policies and programmes dedicated to national and local level institutions could be developed in order to better align the mobility aspect of internationalisation with the internationalisation of the curriculum, teaching and learning. And as a final recommendation, to better understand students' perception of the benefits and risks of internationalisation together with possible improvements within EHEA, more studies at an institutional, national and European level should be done.

Acknowledgments Special thanks go to Baboschi Catalina-Matilda, who helped with the statistical analysis of the questionnaire answers. Her help was more than enlighten in deciphering the underlying truths behind the answers of the students.

\section{References}

ANPCDEFP. (2013). The lifelong learning programme-implementation report for 2013.

ANPCDEFP \& CPEDU. (2015). Internationalisation of Romanian universities through the European Union programmes for education and training-An impact analysis [Internaționalizarea Universităților din România prin Programele Uniunii Europene Pentru Educație Și Formare - Analiză de impact]. Bucharest.

de Wit, H., Hunter, F., Howard, L., \& Polak, E. E. (2015). Internationalisation of Higher Education study, country case study Romania, European Parliament, Bruxelles.

Deca, L., \& Fit, C. (2015). Internationalisation of higher education study, country case study Romania, European Parliament, Bruxelles.

Egron-Polak, E. (2014). Internationalisation of higher education: Converging or diverging trends? International Higher Education, 76, 7-9. 
EHEA. (2012). Making the most of our potential: Consolidating the European higher education area-Bucharest Communiqué, and strengthening mobility for a better learning strategy. Bucharest.

ESIB. (2001). Student participation in higher education area, ESU.

Knight, J. (2008). Higher education in Turmoil: The changing world of internationalisation (p. 21). Rotterdam: Sense Publishers.

Pricopie, R. (2004). Diagnosis analysis-Universities in the context of Europeanization and Globalization, p. 26.

UEFISCDI. (2013). EHEA the global context/internationalisation of education. UEFISCDI, The reflection of the Romania's commitments to the EHEA in the national contex [Reflectarea angajamentelor României în Spațiul European al Învățământului Superior (EHEA) în context național]. Bucharest.

UEFISCDI. (2015). Framework for a national strategy on internationalisation of higher education in Romania 2015. Bucharest.

Open Access This chapter is licensed under the terms of the Creative Commons Attribution 4.0 International License (http://creativecommons.org/licenses/by/4.0/), which permits use, sharing, adaptation, distribution and reproduction in any medium or format, as long as you give appropriate credit to the original author(s) and the source, provide a link to the Creative Commons license and indicate if changes were made.

The images or other third party material in this chapter are included in the chapter's Creative Commons license, unless indicated otherwise in a credit line to the material. If material is not included in the chapter's Creative Commons license and your intended use is not permitted by statutory regulation or exceeds the permitted use, you will need to obtain permission directly from the copyright holder.

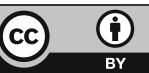

